Chapter 6

\title{
Air Pollution Monitoring: A Case Study from Romania
}

\author{
Gabriela lorga \\ Additional information is available at the end of the chapter
}

http://dx.doi.org/10.5772/64611

\begin{abstract}
The first section of this chapter provides an up-to-date general view of air pollution/air quality topic. It indicates main pollutants and their sources and impacts and presents and discusses current air quality standards and air quality indexes worldwide; how datasets are acquired, gathered and analyzed and how the measurements are then interpreted are also presented. Recent works containing updated and detailed technical discussions for each issue addressed and additional web resources are mentioned. The great importance of air pollution monitoring is emphasized. Second, in the international context of incomplete information on air pollution in East Europe, the chapter includes a section presenting an assessment of air pollution at some sites in Romania together with its evolution from the beginning of the monitoring up to present. Availability of $\mathrm{PM}_{10}, \mathrm{PM}_{2.5}, \mathrm{NO}_{x}, \mathrm{SO}_{2}$ and $\mathrm{CO}$ concentrations is site and pollutant dependent and varies from 3 to 9 years. Investigation of temporal and spatial variation of pollutant levels, as well as of $\mathrm{PM}_{10}$ and $\mathrm{PM}_{2.5}$ relationships with the measured gaseous air pollutants and with meteorological variables, includes correlation and linear regression analysis and temporal-trend analysis; coefficient of divergence was calculated to check up on the air pollution inter-sites' differences and pollutant seasonal variation intra-site.
\end{abstract}

Keywords: air pollution, air quality standards, air quality index, particulate matter, gaseous pollutants, temporal trends, East Europe

\section{An introduction to air pollution monitoring}

The challenge of modern society to take air pollution abatement measures based on scientific knowledge has encouraged the scientists to study the atmospheric composition changes, the short- and long-term pollutant effects and impacts and to simulate air pollution scenarios all over the world. The advances achieved in the field of air pollution during the past decades are 
due to numerous detailed investigations, the application of a large number of techniques and the acquisition of abundant monitoring data.

First, the aim of this chapter is to provide an up-to-date general view of air pollution/air quality topic. Second, in the international context of incomplete information on air pollution in East Europe, the chapter includes a section presenting an updated image of air pollution at some sites in Romania together with its evolution from the beginning of the monitoring up to present.

The substances that accumulate in atmosphere in such a concentration and for enough long time that they may harm the living organisms or produce damage to building materials are called pollutants. World Health Organization gives us the following definition of air pollution: "Air pollution is contamination of the indoor or outdoor environment by any chemical, physical or biological agent that modifies the natural characteristics of the atmosphere." [1] Air pollution can be also defined as "when gases or aerosol particles emitted anthropogenically build up in concentrations sufficiently high to cause direct or indirect damage to plants, animals, other life forms, ecosystems, structures or works of art" [2]. Although both definitions refer to accumulation of a pollutant in atmosphere, the second one is a restrictive definition to anthropogenic influence on air composition. In this respect, the air quality (AQ) collocation, which is often used to express the status of air pollution, can be viewed as a measure of the anthropogenic perturbation of the natural atmospheric state. The quality of the air depends on the amount of pollutants, the rate at which they are released from various sources and how quickly the pollutants are deposited or disperse. Good air quality refers to clean, unpolluted air. The meteorological conditions influence significantly the amount of pollutants in a region: low winds, temperature inversions and topography with mountains can trap the pollutants close to the ground, leading to an increased amount of pollutants over the region. Conversely, the presence of a strong and persistent wind over an area with significant pollutant emissions but located in a plain can disperse very quickly the air pollutants.

Air pollution comes from many different sources such as factories, electrical power and chemical plants, chimneys, landfills, oil refineries, smelters, solid waste disposal farming, home and business activities, etc. In addition, all transportation activities using cars, buses, trucks, trains, boats and airplanes contribute to air pollution. Pollution can also result from wildfires, volcanic eruptions, dust storms or windblown dust. As a result, air pollutants can have natural or anthropogenic sources, could come from mobile (e.g. automobiles) or stationary sources (e.g. industrial facilities), could be emitted by local sources and may travel or be formed over long distances affecting therefore large areas. Pollutants in atmosphere can be primary pollutants (emitted directly to the atmosphere) or secondary pollutants (formed by chemical reactions involving primary pollutants and other constituents within the atmosphere). In highly populated metropolitan areas where air pollutants result from a combination of stationary sources and mobile sources, we encounter the so-called air pollution hotspots.

However, the air pollution refers not only to ambient, outdoor pollution, but also to indoor pollution. Pollution within enclosed spaces, such as schools, homes, building offices and various workplaces, can come from tobacco smoke, mould, chemicals released from household products or synthetic fabrics, different paintings or dyes. This chapter is focused on outdoor pollution. However, I must note a very detailed and recently published report that summarizes 
the main standards and guidelines related to the key indoor air pollutants developed by various international agencies worldwide in reference [3].

Below is an introduction to the most widespread air pollutants together with their main sources, and impacts they can have, pollutants that are frequently monitored in most of the networks (Figure 1).

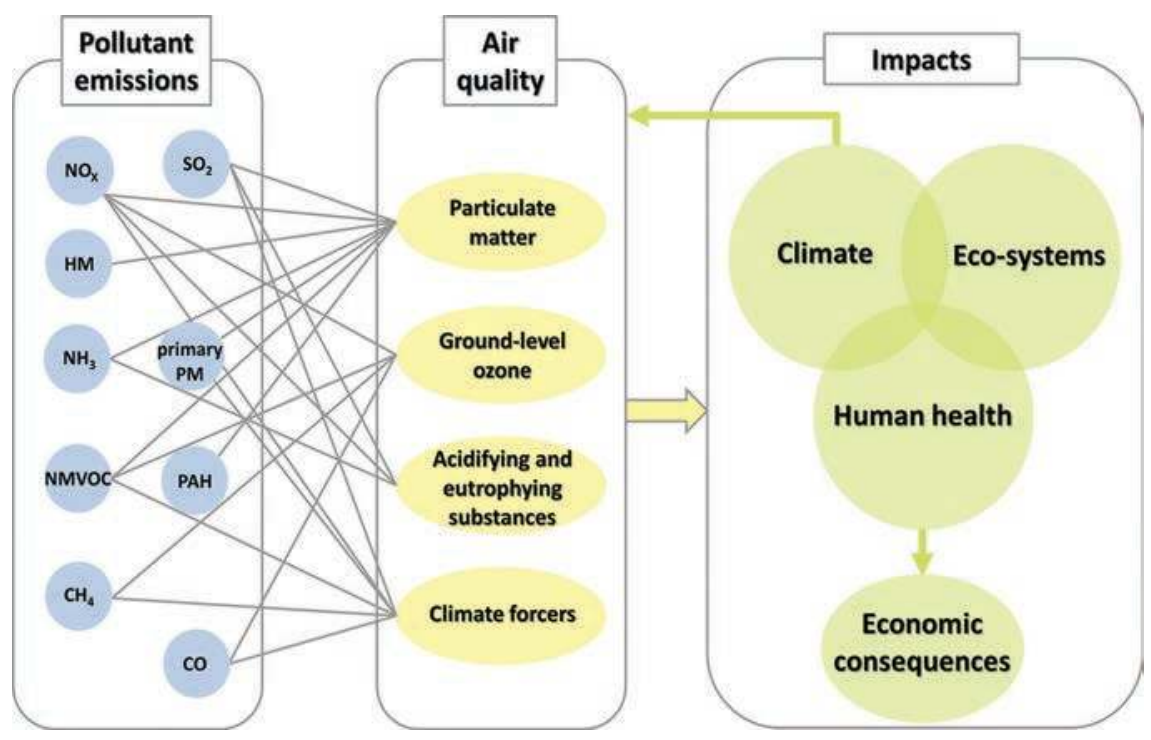

Figure 1. Diagram showing connections between most widespread air pollutants, air quality and impacts. Adapted from brochure [10] and modified.

Particulate matter (PM) in atmosphere is a mixture of particles (solid and liquid) covering a wide range of sizes and chemical compositions. $\mathrm{PM}_{10}\left(\mathrm{PM}_{2.5}\right)$ refers to all particles with a diameter less than $10(2.5) \mu \mathrm{m}$. In cities, PM originates predominantly anthropogenically, from several source categories, such as local industrial emissions, vehicular traffic and long-range transport, and can be enhanced by natural sources of coarse particles not easily controllable (e.g. re-suspended windblown dust, sea salt, etc.). Apart from meteorology, even street configuration and urban morphological characteristics may influence the pollutant accumulation or dispersion via the airflow pattern $[4,5]$. The main precursor gases for secondary PM are sulfur dioxide $\left(\mathrm{SO}_{2}\right)$, nitrogen oxides $(\mathrm{NOx})$, ammonia $\left(\mathrm{NH}_{3}\right)$ and volatile organic compounds (VOCs). PM particles are of major concern because of their potential health impact. Although the specific biological mechanisms are not completely understood, many epidemiological studies [6] show the associations between short- and long-term exposure to PM 
and hospital admissions, medication use, respiratory symptoms and reduced pulmonary function, or even increased mortality. Heart rate alterations associated with exposure to mixtures of ambient concentration of particulate matter, carbon monoxide (CO) and nitrogen dioxide $\left(\mathrm{NO}_{2}\right)$ were observed in epidemiological studies and animal experiments [7]. Health effects are more strongly associated with exposure to fine fraction $\mathrm{PM}_{2.5}$ than to the coarse fraction of $\mathrm{PM}_{10}$ [8], and the risk of their occurrence is especially high in urban areas.

Sulfur dioxide $\left(\mathrm{SO}_{2}\right)$ is an acidic gas formed by oxidation of sulfur (S), mainly through combustion of fossil fuels containing $\mathrm{S}$. The electricity generation sector is the most important source of $\mathrm{SO}_{2}$. Areas where coal is widely used for domestic heating are important sources of $\mathrm{SO}_{2}$, as well. Volcanoes are the biggest natural source of sulfur oxides. $\mathrm{SO}_{2}$ aggravates heart diseases and asthma and can reduce lung function and irritate the respiratory tract. It contributes to the formation of particulate matter, and of acid rain, which damages forests, crops, buildings and ecosystems in rivers and lakes.

Nitrogen oxides (NOx) is the name of a group of highly reactive gases containing nitrogen and oxygen in different amounts. The principal source of NOx is road traffic, but fuel combustion from industrial facilities is another source. Nitrogen monoxide (NO) makes up the majority of NOx emissions, although newer diesel vehicles may emit as much as $55 \%$ of their $\mathrm{NOx}$ as $\mathrm{NO}_{2}$ [9]. Oxidation of $\mathrm{NO}$ emissions also leads to $\mathrm{NO}_{2}$. In the presence of sunlight, $\mathrm{NO}_{2}$ reacts with hydrocarbons and produces photochemical pollutants as ground-level $\mathrm{O}_{3}$. $\mathrm{NO}_{2}$ is associated with adverse effects on health of liver and blood. It can aggravate lung diseases leading to respiratory symptoms and increased susceptibility to respiratory infection. NOx contributes to the formation of particulate matter, to acid deposition and to eutrophication of soil and water.

Carbon monoxide (CO) results from incomplete combustion of fuels but can also be formed by oxidation of hydrocarbons and other organic compounds. Sources of CO include road traffic (high levels of $\mathrm{CO}$ are registered in heavy traffic congestion with old cars and trucks), industrial processes, residential wood burning and forest fires. $\mathrm{CO}$ can react with other pollutants producing ground-level ozone or with $\mathrm{O}_{2}$ creating $\mathrm{CO}_{2}$, which is an important warming agent. In a warmer atmosphere, higher levels of $\mathrm{NO}_{3}$ could appear and thus PM level may increase. $\mathrm{CO}$ can lead to significant reduction of oxygen to heart and central nervous system, and, therefore, headaches, dizziness and fatigue appear.

Non-methane volatile organic compounds (NMVOCs) include a variety of chemicals, coming from both anthropogenic (paints, road transport, dry-cleaning and other solvent uses) and biogenic (vegetation) sources, with the emitted amounts dependent on species and on temperature. Certain NMVOC species, such as benzene $\left(\mathrm{C}_{6} \mathrm{H}_{6}\right)$ and 1,3-butadiene, are directly hazardous to human health. NMVOCs are also precursors of ground-level ozone.

Ground-level ozone $\left(\mathrm{O}_{3}\right)$ is not directly emitted into the atmosphere, but it forms in the atmosphere from a chain of chemical reactions from certain precursor gases: NOx, CO, NMVOCs and methane $\left(\mathrm{CH}_{4}\right)$. It irritates the airways of the lungs, may decrease the lung function and aggravates the asthma even at very low levels. $\mathrm{O}_{3}$ damages plants and ecosystems, 
and it can lead to premature mortality. Ozone is also a greenhouse gas contributing to warming of the atmosphere.

Other pollutants of interest are ammonia $\left(\mathrm{NH}_{3}\right)$ and methane $\left(\mathrm{CH}_{4}\right)$, coming mainly from agriculture, waste management and energy production; benzo[a]pyrene $(\mathrm{BaP})$, resulting from incomplete combustion of various fuels for domestic home-heating, in particular wood and coal burning, waste burning, coke and steel production and road traffic; toxic metals: arsenic (As), cadmium $(\mathrm{Cd})$, lead $(\mathrm{Pb})$ and nickel $(\mathrm{Ni})$, emitted mainly from the combustion of fossil fuels, metal production and waste incineration; and black carbon (BC), which is a product of incomplete combustion of fossil fuels; $\mathrm{BC}$ results mostly from traffic and industry.

Air qusformed in networks of air quality monitoring stations owned by national governments, but regional, provincial administrations or some non-profit organizations might collaborate, too. Nowadays, automatic and/or manual AQ networks operate in numerous countries. The various air pollutants are monitored depending on national or regional interests, network capabilities and/or personnel and funding available. Among the usual determination techniques, the chemiluminescence $\left(\mathrm{NO}_{\mathrm{x}}\right)$, UV fluorescence $\left(\mathrm{SO}_{2}\right)$, non-dispersive infrared spectroscopy $(\mathrm{CO})$, UV photometry $\left(\mathrm{O}_{3}\right)$ and gas chromatography with photo ionization detector $\left(\mathrm{C}_{6} \mathrm{H}_{6}\right)$ find themselves out. Measurements of $\mathrm{PM}_{10}$ and $\mathrm{PM}_{2.5}$ are obtained by gravimetric analysis and those of heavy metals $(\mathrm{Pb}, \mathrm{Cd}, \mathrm{Ni}, \mathrm{As})$ by atomic absorption spectrometry. A presentation of advances in instrumentations and methodologies for measuring atmospheric composition from space, aircraft and the surface can be found in the reference [11], laboratory techniques being also included. Datasets are acquired through measurements made on an hourly or daily average basis, and concentration values are evaluated and reported. The registered volume or mass concentrations, expressed as ppb, ppm or $\mu \mathrm{g} \mathrm{m}^{-3}$ for example, are used to assess and inter-compare the air quality levels at different scales: local, regional and global. When long-term data are available, a long-term trend analysis can be performed. When an assessment of the AQ is desired, the ambient air measurements must be evaluated in conjunction to data on anthropogenic emissions and their trends for all available pollutants, or at least the main pollutants.

Air pollution is mostly regulated by emission standards and taxes and by air quality standards. The air quality standards have scientific basis on epidemiological, toxicological investigations on humans and animals and intensive researches on pollution impact on ecosystems. Because the time pattern of air pollution is important in relation to pollution impacts, the objective of a standard is to establish the limit values and alert thresholds for pollutant concentrations in ambient air with the general aim to avoid, prevent and/or reduce harmful effects on human health and on the environment. Air quality standards are expressed as guidelines (WHO) or standards (US EPA, EU). A detailed review of air quality policy in the USA and the EU, including the main legislation acts and emission standards, is presented in [12], and reference [13] provides a review of air quality management actions. A comparative table on limit values for the main pollutants $\mathrm{SO}_{2}, \mathrm{NO}_{2}, \mathrm{CO}, \mathrm{PM}_{10}$ and $\mathrm{PM}_{2.5}$ including some other countries worldwide is provided in Table 1. 


\begin{tabular}{|c|c|c|c|c|c|c|c|c|c|c|c|}
\hline \multirow[t]{3}{*}{ Pollutant } & \multirow{3}{*}{$\begin{array}{l}\text { Time } \\
\text { period }\end{array}$} & \multicolumn{2}{|c|}{ European Union } & \multirow{2}{*}{$\begin{array}{l}\text { US EPA } \\
\text { NAAQS }\end{array}$} & WHO & Australia & $\begin{array}{l}\text { British } \\
\text { Columbia }\end{array}$ & $\begin{array}{l}\text { South } \\
\text { Africa }\end{array}$ & Mexico & China* & \multirow[t]{2}{*}{ India } \\
\hline & & \multirow[b]{2}{*}{ Value } & \multirow{2}{*}{\multicolumn{4}{|c|}{ Observations }} & \multirow{2}{*}{\multicolumn{5}{|c|}{ Air quality limit value/guideline }} \\
\hline & & & & & & & & & & & \\
\hline \multirow[t]{7}{*}{10} & 1 year & 40,20 & For protection of & 50 & 20 & & & 50 & 50 & 40 & 60 \\
\hline & & & human health & & & & & & & & \\
\hline & & & 35/year, since & & & & & & & & \\
\hline & & & 2010 & & & & & & & & \\
\hline & $24 \mathrm{~h}$ & 50 & For protection of & 150 & 50 & 50 & 50 & 120 & 120 & 50 & 100 \\
\hline & & & human health & 1/year & & & & 4/year & & & \\
\hline & & & 7/year & & & & & & & & \\
\hline \multirow[t]{6}{*}{2.5} & 1 year & 25 & & 15 & 10 & 8 & 8 & & 15 & 100 & 40 \\
\hline & $24 \mathrm{~h}$ & & & 35 & 25 & & & & & & \\
\hline & 1 year & 20 & For protection of & & 50 & 20 & 50 & 50 & $0.03 \mathrm{ppn}$ & 20 & 20 \\
\hline & & & ecosystems & & & & & & & & \\
\hline & $24 \mathrm{~h}$ & 125 & 3/year & 365 & 20 & 80 & 260 & 120 & $0.13 \mathrm{ppn}$ & 50 & 80 \\
\hline & & & & 1/year & & & & 4/year & $1 /$ year & & \\
\hline \multirow[t]{7}{*}{2} & $1 \mathrm{~h}$ & 350 & 24/year & $75 \mathrm{ppb}$ & & 200 & 900 & 350 & & 150 & \\
\hline & & & & & & & & 88/year & & & \\
\hline & $3 \mathrm{~h}$ & & & $0.5 \mathrm{ppm}$ & & & & & & & \\
\hline & & & & year & & & & & & & \\
\hline & $10 \mathrm{~min}$ & & & & 500 & & & & & & \\
\hline & 1 year & 30 & For protection of & & & & & & & & \\
\hline & & & ecosystems & & & & & & & & \\
\hline \multirow[t]{16}{*}{$\mathrm{NO}_{2}$} & 1 year & 40 & For protection of & $53 \mathrm{ppb}$ & 40 & 30 & 60 & 40 & & 40 & 40 \\
\hline & & & human health & & & & & & & & \\
\hline & $24 \mathrm{~h}$ & & & & & & 200 & & & 80 & 80 \\
\hline & $1 \mathrm{~h}$ & 200 & For protection of & $100 \mathrm{ppb}$ & 200 & 120 & 400 & 200 & \multicolumn{2}{|c|}{$0.21 \mathrm{ppm} 120$} & \\
\hline & & & human health & & & & & 88/year & \multirow{2}{*}{\multicolumn{2}{|c|}{ 1/year }} & \\
\hline & & & 18/year & & & & & & & & \\
\hline & 1 year & 120 & Long-term goal & & & & & & & & \\
\hline & & & for protection of & & & & & & & & \\
\hline & & & human health: & & & & & & & & \\
\hline & & & AOT40 from $1 \mathrm{~h}$ & & & & & & & & \\
\hline & & & values within & & & & & & & & \\
\hline & & & period May-July & & & & & & & & \\
\hline & $1 \mathrm{~h}$ & 6000 & Long-term goal & $120 \mathrm{ppb}$ & & & & & & & \\
\hline & & & for protection of & & & & & & & & \\
\hline & & & ecosystems: & & & & & & & & \\
\hline & & & AOT40 from $1 \mathrm{~h}$ & & & & & & & & \\
\hline
\end{tabular}




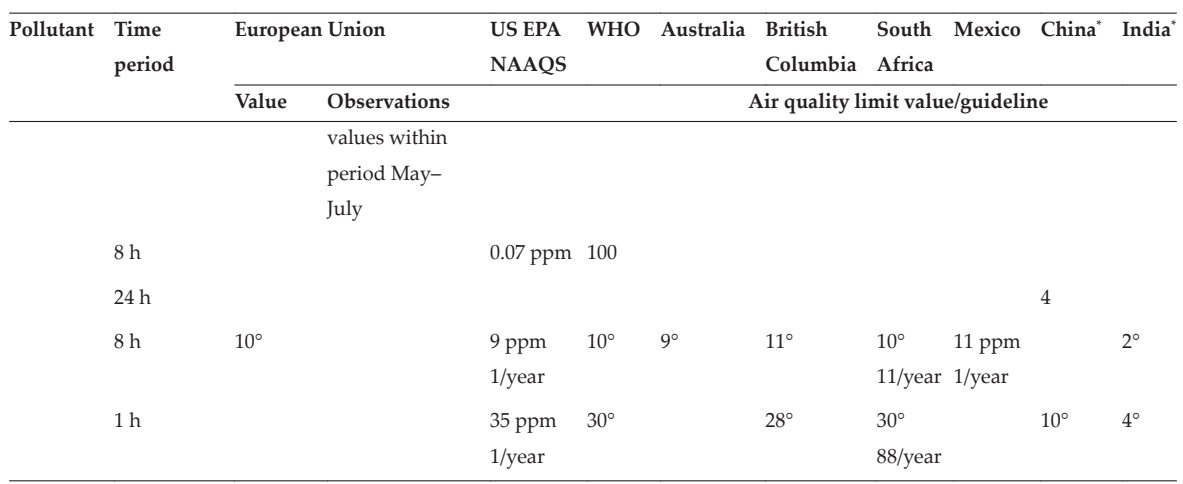

Data compiled from references [13-16].

"China sets standards for three levels of air pollution, here is shown the most restrictive one, for residential areas; ${ }^{+}$for

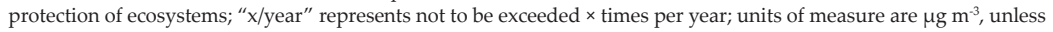
where ${ }^{\circ}$ is indicated, when $\mathrm{mg} \mathrm{m}^{-3}$ must be considered; $\mathrm{ppm}$ - parts per million; ppb-parts per billion.

Table 1. Comparison of current worldwide air quality limit or target values/guidelines.

The data from monitoring stations are also used to calculate air quality index (AQI). This is a common way to present to the people the air quality status by the government agencies, in both developed and developing countries. The higher the AQI value, the higher the percentage of the population that is likely to experience severe adverse health effects. AQI can be calculated for both short (hourly, daily) and for long-term (annual) periods. AQI is constructed in order to match the air quality standards of the country where it is used. A general formula to compute an AQI is the following:

$$
\mathrm{AQI}_{\text {pollutant }}=\frac{\text { pollutant concentration reading }}{\text { standard concentration }} \times 100
$$

The AQI is generally based on a number of subindices for individual pollutants. The classification of air quality is based on the subindex with the highest value. Currently, there are numerous AQIs, but we do not have a methodology internationally accepted to construct these indexes. Most of them are defined using the main common gaseous pollutants: $\mathrm{CO}, \mathrm{NO}_{2}, \mathrm{O}_{3}$, $\mathrm{SO}_{2}$ and particulate matter $\left(\mathrm{PM}_{10}\right.$ and $\left.\mathrm{PM}_{2.5}\right)$. Sometimes, other pollutants, such as $\mathrm{C}_{6} \mathrm{H}_{6}, \mathrm{NH}_{3}$ or $\mathrm{Pb}$, are added. Table 2 presents a compilation of some current existing AQI, the health risk category and implications for the population. At the end of Table 2, the AQ classification, the color code and how the AQI is computed, as provided by Rhenish Institute for Environmental Research at the University of Cologne (EURAD), are shown [17]. For the rest of the regions included in Table 2, the appropriate references for AQI calculation are provided. 
Most state or local agencies report the AQI on their public web sites. Real-time monitoring data and forecasts of air quality that are color coded in terms of the air quality index are available from US Environmental Protection Agency's AirNow web site www.airnow.gov. Real-time AQI visual map for more than 60 countries over the world is available at https:// waqi.info. To convert an air pollutant concentration to an AQI or conversely, EPA has also developed a calculator [23]. As one observes, the AQI is country or city specific, and even the interpretation of an AQI varies considerably from one region to other; this makes the comparison of calculated values in various regions difficult. To minimize these difficulties within its boundaries and to facilitate the international comparison of near real time of $A Q$, European Union introduced in 2006 the Common AQI in the framework of CITEAIR Project [22]. Moreover, the AQIs do not take into account the coexistence of all the air pollutants. Reference [24] shows how a multi-pollutant and multi-site AQI could be designed in order to get an aggregate measure of air pollution. However, the AQI has the advantage to concentrate multiple and multi-scale measurements in a unique indicator and allows to follow the evolution of air quality in a given region or city providing timely and understandable information for population and supporting local authorities governments in decisions to prevent and avoid adverse health effects. Critical and comparative reviews of the existing AQIs and proposal of alternatives are provided by references [25-27].

\begin{tabular}{|c|c|c|c|}
\hline \multicolumn{4}{|l|}{ Canada [18] } \\
\hline \multirow{2}{*}{$\begin{array}{l}\text { Health risk } \\
\text { category }\end{array}$} & \multirow[t]{2}{*}{ AQHI } & \multicolumn{2}{|c|}{ Health messages } \\
\hline & & At risk population & General population \\
\hline Low & $1-3$ & Enjoy your usual outdoor activities & Ideal air quality for outdoor activities \\
\hline Moderate & $4-6$ & $\begin{array}{l}\text { Consider reducing or reschedu } \\
\text {-ling strenuous activities outdoors } \\
\text { if you are experiencing symptoms }\end{array}$ & $\begin{array}{l}\text { No need to modify your usual outdoor } \\
\text { activities unless you experience symptoms } \\
\text { such as coughing and throat irritation }\end{array}$ \\
\hline High & $7-10$ & $\begin{array}{l}\text { Reduce or reschedule strenuous } \\
\text { activities outdoors. Children } \\
\text { and the elderly should also } \\
\text { take it easy }\end{array}$ & $\begin{array}{l}\text { Consider reducing or rescheduling strenuous } \\
\text { activities outdoors if you experience symptoms } \\
\text { such as coughing and throat irritation }\end{array}$ \\
\hline Very high & Above 10 & $\begin{array}{l}\text { Avoid strenuous activities outdoors. } \\
\text { Children and the elderly should also } \\
\text { avoid outdoor physical exertion }\end{array}$ & $\begin{array}{l}\text { Reduce or reschedule strenuous activities } \\
\text { outdoors, especially if you experience symptoms } \\
\text { such as coughing and throat irritation }\end{array}$ \\
\hline \multicolumn{4}{|l|}{ China [19] } \\
\hline $\begin{array}{l}\text { Air pollution } \\
\text { (color code) }\end{array}$ & evel AQI & Health implications & Cautionary statement (for $\mathbf{P M}_{2.5}$ ) \\
\hline Good (green) & $0-50$ & $\begin{array}{l}\text { Air quality is considered } \\
\text { satisfactory, and air pollution poses } \\
\text { little or no risk }\end{array}$ & None \\
\hline
\end{tabular}




\begin{tabular}{|c|c|c|c|}
\hline China [19] & & & \\
\hline $\begin{array}{l}\text { Air pollution level } \\
\text { (color code) }\end{array}$ & AQI & Health implications & Cautionary statement (for $\mathbf{P M}_{2.5}$ ) \\
\hline Moderate (yellow) & $51-100$ & $\begin{array}{l}\text { Air quality is acceptable; however, } \\
\text { for some pollutants there may be a } \\
\text { moderate health concern for a very } \\
\text { small number of people who are } \\
\text { unusually sensitive to air pollution }\end{array}$ & $\begin{array}{l}\text { Active children and adults, and people with } \\
\text { respiratory disease, such as asthma, should limit } \\
\text { prolonged outdoor exertion }\end{array}$ \\
\hline $\begin{array}{l}\text { Unhealthy for } \\
\text { sensitive groups } \\
\text { (orange) }\end{array}$ & $101-150$ & $\begin{array}{l}\text { Members of sensitive groups may } \\
\text { experience health effects. The } \\
\text { general public } \\
\text { is not likely to be affected }\end{array}$ & $\begin{array}{l}\text { Active children and adults, and people with } \\
\text { respiratory disease, such as asthma, should limit } \\
\text { prolonged outdoor exertion }\end{array}$ \\
\hline Unhealthy (red) & $151-200$ & $\begin{array}{l}\text { Everyone may begin to experience } \\
\text { health effects; members of } \\
\text { sensitive groups may experience } \\
\text { more serious health effects }\end{array}$ & $\begin{array}{l}\text { Active children and adults, and people with } \\
\text { respiratory disease, such as asthma, should avoid } \\
\text { prolonged outdoor exertion; everyone else, } \\
\text { especially children, should limit prolonged outdoor } \\
\text { exertion }\end{array}$ \\
\hline $\begin{array}{l}\text { Very unhealthy } \\
\text { (purple) }\end{array}$ & $201-300$ & $\begin{array}{l}\text { Health warnings of emergency } \\
\text { conditions. The entire } \\
\text { population is more likely to be } \\
\text { affected }\end{array}$ & $\begin{array}{l}\text { Active children and adults, and people with } \\
\text { respiratory disease, such as asthma, should avoid } \\
\text { all outdoor exertion; everyone else, especially } \\
\text { children, should limit outdoor exertion }\end{array}$ \\
\hline $\begin{array}{l}\text { Hazardous } \\
\text { (maroon) }\end{array}$ & $\begin{array}{l}\text { Above } \\
300\end{array}$ & $\begin{array}{l}\text { Health alert: everyone may } \\
\text { experience more serious health } \\
\text { effects }\end{array}$ & Everyone should avoid all outdoor exertion \\
\hline
\end{tabular}

\begin{tabular}{|c|c|c|}
\hline India [20] & & \\
\hline $\begin{array}{l}\text { Air pollution } \\
\text { level }\end{array}$ & AQI & Associated health impacts \\
\hline Good & $0-50$ & Minimal impact \\
\hline Satisfactory & $51-100$ & May cause minor breathing discomfort to sensitive people \\
\hline $\begin{array}{l}\text { Moderately } \\
\text { polluted }\end{array}$ & $101-200$ & $\begin{array}{l}\text { May cause breathing discomfort to people with lung disease such as asthma, and } \\
\text { discomfort to people with heart disease, children and older adults }\end{array}$ \\
\hline Poor & $201-300$ & $\begin{array}{l}\text { May cause breathing discomfort to people on prolonged exposure, and discomfort to } \\
\text { people with heart disease }\end{array}$ \\
\hline Very poor & $301-400$ & $\begin{array}{l}\text { May cause respiratory illness to the people on prolonged exposure. Effect may be more } \\
\text { pronounced in people with lung and heart diseases }\end{array}$ \\
\hline Severe & $401-500$ & $\begin{array}{l}\text { May cause respiratory impact even on healthy people, and serious health impacts on } \\
\text { people with lung/heart disease. The health impacts may be experienced even during light } \\
\text { physical activity }\end{array}$ \\
\hline
\end{tabular}




\begin{tabular}{|c|c|c|c|}
\hline \multicolumn{4}{|l|}{ US EPA [21] } \\
\hline $\begin{array}{l}\text { Level of health concern } \\
\text { (color code) }\end{array}$ & AQI & Sensitive groups & General population \\
\hline Good (green) & $0-50$ & None & None \\
\hline Moderate (yellow) & $51-100$ & $\begin{array}{l}\text { Unusually sensitive individuals may experience } \\
\text { respiratory symptoms }\end{array}$ & None \\
\hline $\begin{array}{l}\text { Unhealthy for sensitive } \\
\text { groups (orange) }\end{array}$ & $101-150$ & $\begin{array}{l}\text { Increasing likelihood of respiratory symptoms } \\
\text { and breathing discomfort in active children and } \\
\text { adults and people with lung disease, such as } \\
\text { asthma }\end{array}$ & None \\
\hline Unhealthy (red) & $151-200$ & $\begin{array}{l}\text { Greater likelihood of respiratory symptoms and } \\
\text { breathing difficulty in active children and adults, } \\
\text { people should reduce prolonged or heavy } \\
\text { outdoor exertion }\end{array}$ & Possible respiratory effects \\
\hline Very unhealthy (purple) & $201-300$ & $\begin{array}{l}\text { Increasing severity of cardiovascular symptoms } \\
\text { and impaired breathing likely in active children } \\
\text { and adults and people with lung diseases }\end{array}$ & $\begin{array}{l}\text { Significant increase in } \\
\text { respiratory symptoms }\end{array}$ \\
\hline Hazardous (maroon) & $301-500$ & $\begin{array}{l}\text { Serious aggravation of heart or lung disease and } \\
\text { premature mortality in people with } \\
\text { cardiopulmonary disease and older adults }\end{array}$ & $\begin{array}{l}\text { Serious risk of respiratory } \\
\text { effects in general population }\end{array}$ \\
\hline
\end{tabular}

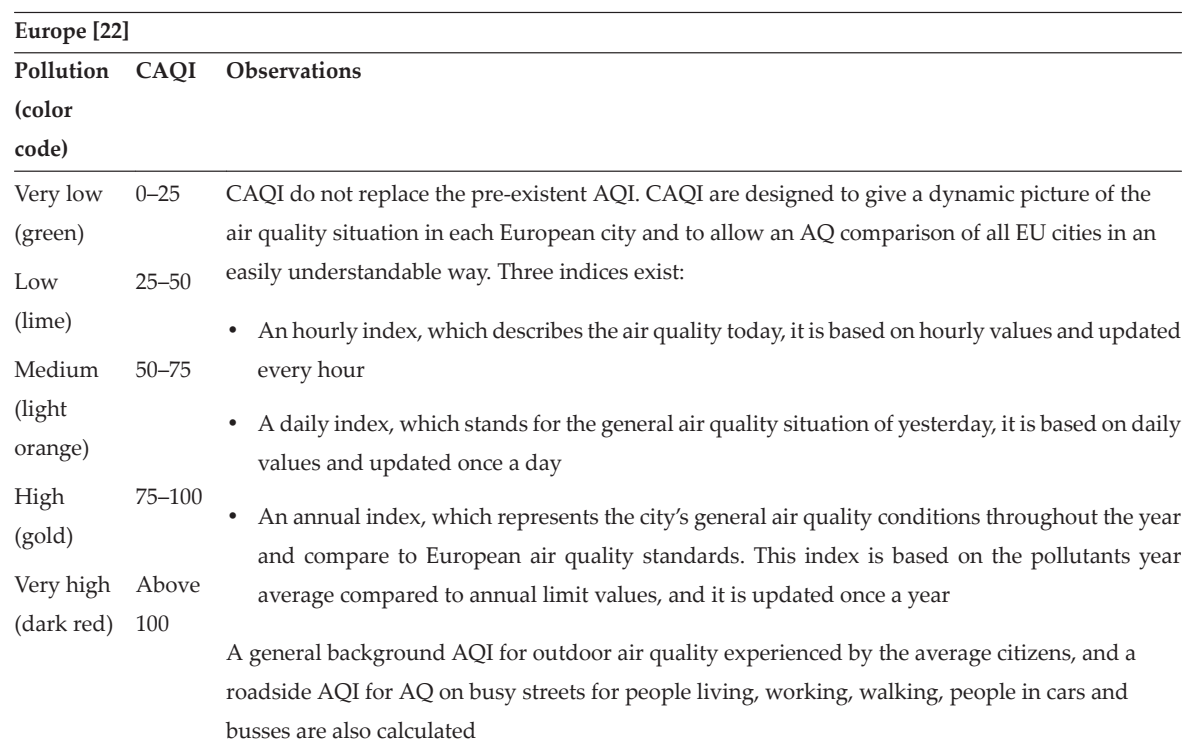


AQ category, AQI and code color as provided by EURAD [17]

$$
A Q I=\operatorname{Max}\left(\frac{O_{3}(24 h)}{100}, \frac{\mathrm{NO}_{2}(24 h)}{90}, \frac{\mathrm{PM}_{10}(24 h)}{50}, \frac{\mathrm{SO}_{2}(24 h)}{125}, \frac{\mathrm{CO}(24 h)}{10000}\right) \times 50
$$

\begin{tabular}{|c|c|c|c|c|}
\hline very good & good & satisfactory & suffident & poor \\
\hline below 10 & $10-20$ & $20-30$ & $30-50$ & $50-80$ \\
\hline
\end{tabular}

Data compiled from references indicated in table for each location.

Table 2. Examples of current worldwide Air Quality Index by location (country, region or city).

Apart from evaluation of air quality at various spatial scales, air pollution monitoring provides essential information to validate the predictive methods and dispersion models, which represent an important set of tools for simulating air pollution scenarios.

One concern that must be mentioned here is the future changes in air quality that will result from climate changes. Many studies indicated a warmer and a more humid climate, with a higher frequency of occurrence of heat waves, of stronger local storms and a higher probability of decrease in frequency of mid-latitude cyclones. Shortly, a warmer and more humid climate will increase the $\mathrm{CO}_{2}$ and VOC levels, will determine (region-specific) increases or decreases of $\mathrm{O}_{3}$, a greater conversion of $\mathrm{SO}_{2}$ to sulfate will take place, and patterns of $\mathrm{NOx}$ will be affected. Due to an increased presence of reactive gaseous species even $\mathrm{PM}_{2.5}$ speciation might be changed, and this will, in turn, affect the Earth's radiative balance. Simulations of future changes in air quality that will result from changes in both meteorological forcing and air pollutant emissions are presented by Glotfelty et al. [28] up to 2050 following the IPCC AR4 SRES A1B scenario. It shows that global air quality is projected to degrade by the mid-21st century on global average, but the changes are regional in nature: for example, $\mathrm{PM}_{2.5}$ level will reduce in Europe and Africa, whereas it will increase in South and Southeast Asia, Indonesia, Australia and South America.

Moreover, thinking about the future long-term air pollution, we must also consider that changes in future air quality will have economic consequences whose projections must be also analyzed. With respect to this, the very recent report "The Economic Consequences of Outdoor Air Pollution" [29] supplies us with a comprehensive assessment of the regional and global economic consequences of outdoor air pollution for the period 2015-2060. Linking the pollutant emissions to labor productivity, healthcare expenditures and changes in crop yields (market costs) and to mortality and morbidity/illness (non-market costs), the projections are indeed of great concern, even if they are subject to uncertainties. The results indicate, among other consequences, that "by 2060, a large number of deaths are projected to take place in densely populated regions with high concentrations of $\mathrm{PM}_{2.5}$ and $\mathrm{O}_{3}$ (especially China and India) and in regions with aging populations, such as China and Eastern Europe. The projected mortality effects of $\mathrm{PM}_{2.5}$ exposure are much larger than those of $\mathrm{O}_{3}$. The market costs of air pollution, flowing from reduced labor productivity, additional health expenditures and crop yield losses, are projected to lead to global annual economic costs of $1 \%$ of global gross domestic product (GDP) by 2060. The projected GDP losses are especially large in China $(-2.6 \%)$, the 
Caspian region (-3.1\%) and Eastern Europe (Non-OECD EU -2.7\% and Other Europe -2.0\%), where air pollution impacts lead to a reduction in capital accumulation and a slowdown in economic growth. In per capita terms, the average global welfare costs from mortality and morbidity are projected to increase from less than USD 500 per person in 2015 to around USD 2 100-2 800 in 2060" [29].

One can, therefore, have an idea about the severe global economic consequences of air pollution and the need of stronger policies to improve the air quality results to be of huge importance for all of us. Within this context, to monitor air pollutants is of great necessity of two-fold importance: in order to take informed decisions, to develop and strengthen the political strategies when the societal and economic challenges are addressed and also to respond to the scientific questions of atmospheric sciences.

\section{Case study: assessment of air pollution over Northern Romania}

\subsection{The air pollution monitoring in Romania}

A systematic air pollution monitoring in Romania started in early 2000s, beginning with Bucharest, the capital of Romania, and has been gradually developed to the rest of the country. Before 2000s, air pollution was investigated in some fixed points of interest (next to industrial sources, traffic hot spots, parks...) only by manual sampling. The number of fixed sampling points was city dependent and variable in time (for example, Bucharest had between 14 and 5 sampling points); decreasing trend was due to technical issues; $30 \mathrm{~min}$ and sometimes $24 \mathrm{~h}$ were used as sampling periods for total suspended particles (TSP) and gases $\mathrm{NO}_{2}, \mathrm{SO}_{2}$, $\mathrm{CH}_{2} \mathrm{O}, \mathrm{NH}_{3}$ and $\mathrm{O}_{3}$; and TSP were sometimes selectively analyzed for their content of $\mathrm{Pb}, \mathrm{Cd}$, $\mathrm{Zn}$ and $\mathrm{Cu}$, experimental methods used not being reported. Measured data indicated frequent exceedances of the maximum admitted concentrations (CMA) at that time. For example, between 1996 and 2000 in Bucharest, TSP levels ranged from 150 to $350 \mu^{-3}$ (annual average), CMA being of $500 \mu \mathrm{g} \mathrm{m}^{-3}$. I do not analyze the air pollution before 2000 , as measurements were done following local protocols, and the imposed thresholds varied in time, were country specific and were not correlated with the regulations worldwide. All these make the comparison of registered pollutant concentrations in those times with data from other cities very difficult and of very limited usefulness.

Nowadays, a number of 143 monitoring stations of all types, traffic, industrial, urban background, rural and remote background, operate at the country scale. Within the context of air quality monitoring in Europe, reports of the National Environmental Protection Agency (owner of the National Air Quality automatic Monitoring Network) are focused only on compliances with the European Union regulations counting exceedances of the limit values. The very few addressed topics regarding air pollution using some monitoring data in few cities are presented in references [30-35]. Most extensive review image of the air pollution problem in Bucharest metropolitan area was published in 2015 by Iorga et al. [16, 36].

The following part of the chapter focuses on the assessment and analysis of daily concentrations of major pollutants using the longest monitoring datasets available at present. 


\subsection{Description of selected stations, data and methods}

I selected two urban sites in cities (medium-size) of national importance (Iasi, Cluj-Napoca), with regional role and potential influence at European scale, a regional background site in mountains (Miercurea Ciuc) and the single remote rural background site (Poiana Stampei) for which Romania reports data within EMEP, the European Monitoring and Evaluation Programme for Transboundary Long-Range Transported Air Pollutants (Figure 2 and Table 3). The selected sites are located in different climatic regions of the country have different topography and are expected to be impacted by different pollution sources.

Iasi (IS) is the largest city in North-East Romania; it is located between northernmost hill and a plain, surrounded by uplands, woods and a valley. Iasi has a humid, continental-type climate with summers wetter than winters, with four distinct seasons. Pollution comes from vehicular traffic with old vehicle fleet, construction works, two thermo-electrical power stations and a lack of green spaces. An international airport is located $8 \mathrm{~km}$ east of the city center.

Cluj-Napoca $(\mathrm{CN})$ represents the second most populated city in North-West Romania, with a metropolitan area exceeding 420,000 inhabitants. Located in a river valley, surrounded by forests and grasslands, it has a continental climate characterized by warm dry summers and cold winters. Some West-Atlantic influences are present during winter and autumn. The city is an important knob of the European network roads, connecting the country with Western Europe. It has the second main airport in Romania, after Bucharest, at $9 \mathrm{~km}$ in its eastern part. Cluj-Napoca has a large industrial park with modern facilities and is an important regional commercial centre, and tourism is well developed in the area. The heating system in Cluj is modern and based on natural gas.

Miercurea Ciuc (MC) is a small city located in a basin surrounded by high mountains with rural settlements. The lowest temperature in the country is frequently registered here. The AQ monitoring station installed here is categorized as rural regional. No major industry exists here; tourism provides the main activities.

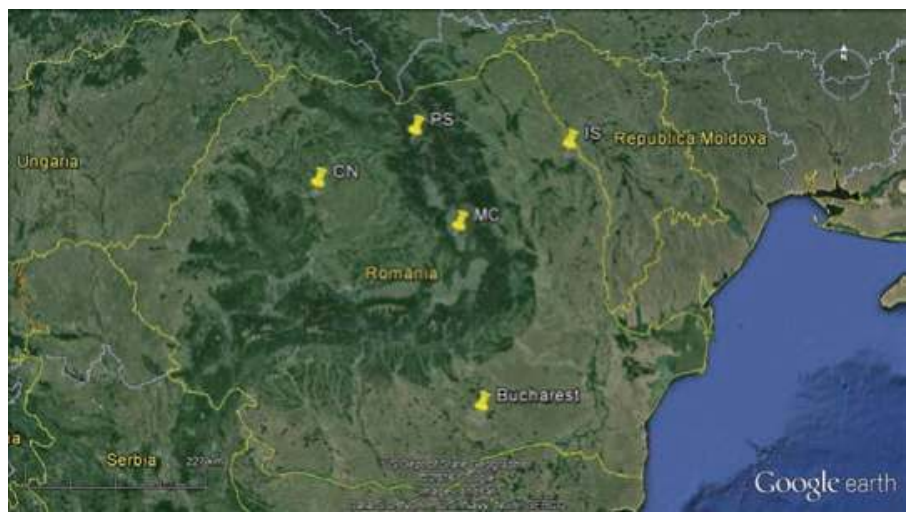

Figure 2. Map showing Romania and the air quality monitoring stations included in present research. 
Poiana Stampei (PS) is a very small village in North Romania, at the border between the two historical provinces Moldavia in East and Transylvania in West. Over 73\% of the village area is represented by forests, and agricultural activity is made with rudimentary field craft.

The air pollution in above sites is compared here with the urban background air pollution in Bucharest, the capital of Romania. Bucharest (approx. $44^{\circ} 26^{\prime} \mathrm{N}, 26^{\circ} 06^{\prime} \mathrm{E}$ ) represents the most developed city of the country and is located at a relatively equal distance from the Danube River and Carpathian Mountains. The Air Quality Network of Bucharest consists of eight stations that are distributed at different spatial levels (inner core city, larger urban zone and sub-city area) covering the main types of anthropogenic activities. Detailed information about Bucharest can be found in reference [16].

\begin{tabular}{|c|c|c|c|c|c|}
\hline $\begin{array}{l}\text { Station name, site } \\
\text { designation } \\
\text { (population) }\end{array}$ & Station type & Latitude & Longitude & $\begin{array}{l}\text { Altitude } \\
\text { (m a.s.l.) }\end{array}$ & $\begin{array}{l}\text { Pollutants included in analysis } \\
\text { and the start year of monitoring }\end{array}$ \\
\hline $\begin{array}{l}\text { Poiana Stampei, PS } \\
(837)\end{array}$ & $\begin{array}{l}\text { Remote rural } \\
\text { background }\end{array}$ & $47^{\circ} 19^{\prime} 30^{\prime \prime} \mathrm{N}$ & $25^{\circ} 08^{\prime} 04^{\prime \prime} \mathrm{E}$ & 908 & $\begin{array}{l}\mathrm{PM}_{10}(2010), \mathrm{NOx}(2010), \mathrm{O}_{3}(2010) \\
\mathrm{SO}_{2}(2010), \mathrm{CO}(2010)\end{array}$ \\
\hline $\begin{array}{l}\text { Miercurea Ciuc, MC } \\
(37 \text { 176) }\end{array}$ & Regional rural & $46^{\circ} 21^{\prime} 34^{\prime \prime} \mathrm{N}$ & $25^{\circ} 48^{\prime} 06^{\prime \prime} \mathrm{E}$ & 710 & $\begin{array}{l}\mathrm{PM}_{10} \text { (2009), } \mathrm{NO}_{\mathrm{x}}(2009), \mathrm{O}_{3}(2008), \\
\mathrm{SO}_{2}(2009), \mathrm{CO}(2009)\end{array}$ \\
\hline $\begin{array}{l}\text { Cluj-Napoca, CN } \\
(324576)\end{array}$ & $\begin{array}{l}\text { Urban } \\
\text { background }\end{array}$ & $46^{\circ} 46^{\prime} 26^{\prime \prime} \mathrm{N}$ & $23^{\circ} 35^{\prime} 49^{\prime \prime} \mathrm{E}$ & 333 & $\begin{array}{l}\mathrm{PM}_{10}(2007), \mathrm{PM}_{2.5}(2009), \mathrm{NO}_{\mathrm{x}} \\
(2006), \mathrm{O}_{3}(2006), \mathrm{SO}_{2}(2006), \mathrm{CO}(2006)\end{array}$ \\
\hline $\begin{array}{l}\text { Iasi, IS } \\
\text { (290 422) }\end{array}$ & $\begin{array}{l}\text { Urban } \\
\text { background }\end{array}$ & $47^{\circ} 09^{\prime} 25^{\prime \prime} \mathrm{N}$ & $27^{\circ} 35^{\prime} 25^{\prime \prime} \mathrm{E}$ & 44 & $\begin{array}{l}\mathrm{PM}_{10}(2006), \mathrm{PM}_{2.5}(2009), \mathrm{NO}_{\mathrm{x}} \\
(2006), \mathrm{O}_{3}(2006), \mathrm{SO}_{2}(2006), \mathrm{CO}(2006)\end{array}$ \\
\hline $\begin{array}{l}\text { Bucharest Greater } \\
\text { Area (2 } 272 \text { 163), }\end{array}$ & $\begin{array}{l}\text { Urban } \\
\text { background }\end{array}$ & $44^{\circ} 26^{\prime} 33^{\prime \prime} \mathrm{N}$ & $26^{\circ} 03^{\prime} 36^{\prime \prime} \mathrm{E}$ & 90 & $\mathrm{PM}_{10}, \mathrm{PM}_{2.5}, \mathrm{NO}_{x}, \mathrm{SO}_{2}, \mathrm{CO}, \mathrm{O}_{3}$ \\
\hline Lacul Morii, LM & & & & & \\
\hline
\end{tabular}

Last monitoring year is 2013 for all sites and pollutants. The sampling periods and detailed analysis of pollution corresponding to the selected station in Bucharest used here for comparison are presented in references [36, 39].

Table 3. Stations, monitored pollutants and beginning year of monitoring.

Data used in the present study are extracted from AirBase v.8 database [37] of European Environment Agency (EEA) for background stations in above locations. However, in order to have completeness of data series for Iasi, some $\mathrm{PM}_{2.5}$ data were added from a traffic station. Availability of the concentrations is site and pollutant dependent and varies from 3 to 9 years. Most data cover the period from January 1, 2006 to December 31, 2013. I focus here on $\mathrm{PM}_{10}$ and $\mathrm{PM}_{2.5}$, and $\mathrm{NO}_{\mathrm{x}}, \mathrm{SO}_{2}$ and $\mathrm{CO}$ (Table 3), as primary gaseous pollutants that accumulate in urban atmosphere and significantly contribute to the photochemical formation of ozone and 
other oxidants and to a fraction of the particulate matter [38]. $\mathrm{O}_{3}$ daily averages were added in order to seek if they could help to better understand the correlations between particulates and primary gaseous pollutants.

A synthetic database of daily averaged datasets of pollutants from AirBase and local meteorology series (air temperatures, relative humidity, atmospheric pressure, wind speed and direction) was prepared in order to have completeness for all sites for common time periods per site, as Table 3 specifies. When it was necessary, conversion of hourly gaseous pollutants and local meteorology data to daily averages was done by averaging over $24 \mathrm{~h}$ periods from midnight to midnight.

Last monitoring year is 2013 for all sites and pollutants. The sampling periods and detailed analysis of pollution corresponding to the selected station in Bucharest used here for comparison are presented in references $[36,39]$.

Statistical examination of temporal and spatial variation of $\mathrm{PM}_{10}$ and $\mathrm{PM}_{2.5}$ concentrations, as well as their relationships with the measured gaseous air pollutants and meteorological variables, includes:

- Correlation analysis, expressed by Pearson coefficients (COR), statistically significant at 95\% confidence interval.

- Single and multiple linear regression analysis, between daily PM as dependent variable and meteorological factors and gaseous pollutants as independent variables, respectively.

- Temporal trend analysis for detecting and estimating a monotonic annual and seasonal trend of ambient pollutant concentrations was performed using the non-parametric MannKendall's test and Sen's method using MAKESENS software [40].

- Coefficient of divergence (COD), a self-normalizing parameter, was applied to evaluate the differences in the average concentrations of pollutants at each site for paired seasons and to compare monitoring sites. COD provides information on the degree of uniformity between monitoring stations and seasons. For example, a low COD and a high COR are expected for sites impacted by similar pollution sources. A COD value between 0 and 0.2 will indicate uniformity, and a COD between 0.4 and 1 will indicate heterogeneity. The coefficient of divergence is calculated as:

$$
C O D_{j k}=\sqrt{\frac{1}{p} \sum_{1}^{p}\left(\frac{x_{i j}-x_{i k}}{x_{i j}+x_{i k}}\right)^{2}}
$$

where $j$ and $k$ stand for the two seasons being compared, $p$ is the number of components investigated and $x i j$ and $x i k$ represent the average mass concentrations of pollutant $i$ during seasons $j$ and $k ; j$ and $k$ stand for different sites when COD definition was applied to inter-site comparisons. 


\subsection{Emissions}

Inventories of emitted air pollutants have been substantially improved during the past few years, in particular for main pollutants, including fine particulates and ozone. WebDab contains all emission data officially submitted to the secretariat of the Convention on Longrange Transboundary Air Pollution (LRTAP Convention) by Parties to the Convention [41]. Romania updated its reports to the emission database WebDab of EMEP in 2015. Pollutant emission trends per site (Figure 3) were evaluated using the gridded data from WebDab for the corresponding time periods of ambient mass concentrations of pollutants, considering the national total economic sectors.
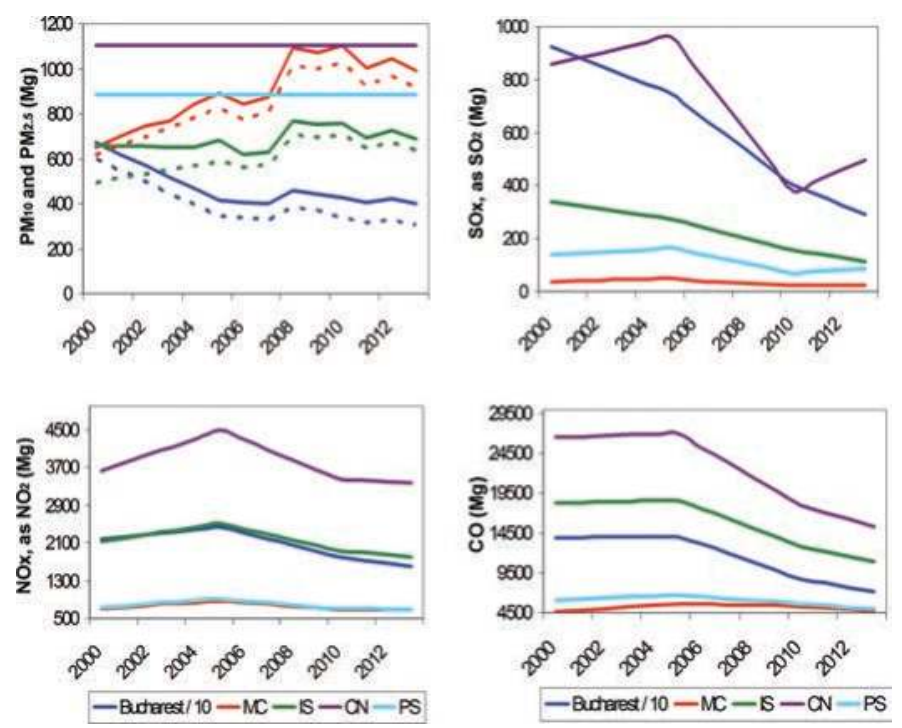

Figure 3. Pollutant emission trends per site as resulted from WebDab emission database, for national total economic sectors. Dotted lines represent $\mathrm{PM}_{2.5}$ emissions. Bucharest emissions are included for comparison.

As shown in Figure 3, the total emissions of gaseous pollutants decreased for all sites, especially starting with 2006, whereas the $\mathrm{PM}_{10}$ and $\mathrm{PM}_{2.5}$ emissions show a different pattern: positive trends for IS and MC and stable emissions for CN and PS sites. Even if the particulate emissions in Bucharest are 10 times higher than in all other sites, due to implementation of the environmental development plan, Bucharest has decreased its particulate emissions from about 5970 $\mathrm{Mg}$ in 2000 to $3060 \mathrm{Mg}$ in 2013. Emissions of PM seem to be of major concern among the pollutants in Romania. The decreasing trend of gaseous emissions follows the general decreasing trend of emissions $\left(\mathrm{SO}_{2}\right.$ decreased by $58 \%$, NOx and $\mathrm{CO}$ by about $25 \%$ ) at EU scale [42], the strongest decrease being for $\mathrm{SO}_{2}$ (range: $34 \%$ for $\mathrm{MC}-66 \%$ for IS), followed by $\mathrm{CO}$ (range: $1 \%$ for $\mathrm{MC}-42 \%$ for $\mathrm{CN}$ ). 


\subsection{Ambient pollutant concentrations}

\subsubsection{Levels of $\mathrm{PM}_{10}, \mathrm{PM}_{2.5}, \mathrm{NOx}, \mathrm{CO}, \mathrm{SO}_{2}, \mathrm{O}_{3}$}

Particulate matter and gaseous pollutant variability are presented in detail in Figure 4 . Figure $4 \mathrm{a}$ and $4 \mathrm{~b}$ provides a box-plot comparison of the annual levels of daily averages of $\mathrm{PM}_{10}$ and $\mathrm{PM}_{2.5}$ mass concentrations by site for the corresponding monitoring periods, including EU limit values [43]. Measured ambient annual (mean, median and $95^{\text {th }}$ percentile) $\mathrm{PM}_{10}$ concentrations have the highest values at IS urban site and the lowest at PS remote site; at all sites, observations situate below the EU limits with the exception of IS city, where in 2013 a value of $44.64 \pm 20.78 \mu \mathrm{g} \mathrm{m}^{-3}$ has been reached. This value is comparable with the value of $45.10 \mu \mathrm{g} \mathrm{m}^{-3}$ representing the mean $\mathrm{PM}_{10}$ concentration during 2005-2010 in Bucharest, when a decrease from about 46 to $35 \mu \mathrm{g} \mathrm{m}{ }^{-3}$ was registered. Concentrations higher than $100 \mu \mathrm{g} \mathrm{m}^{-3}$ appear very often at IS (and more frequent than in Bucharest in 2010 [16, 36]) and even in the alpine basin of MC, although here 95th percentile data are below $100 \mu \mathrm{g} \mathrm{m}^{-3}$. The cleanest air appears to be in PS (mean concentration of $15 \mu \mathrm{g} \mathrm{m}^{-3}$ in 2013), and the urban city CN is the second in rank. $\mathrm{PM}_{2.5}$ levels exceed frequently the EU target of $25 \mu \mathrm{g} \mathrm{m} \mathrm{m}^{-3}$ at both urban sites. Our observations fit very well within the range of European concentrations (from about 20 $\mu \mathrm{g} \mathrm{m} \mathrm{m}^{-3}$ (Finland) to about $75 \mu \mathrm{g} \mathrm{m}^{-3}$ (Bulgaria)), data extracted from Ref. [42] based on 90.4 percentile of daily mean concentration values corresponding to the 36 th highest daily mean in 2013.

The average of $\mathrm{PM}_{2.5} / \mathrm{PM}_{10}$ mass concentration ratios situates between 0.38 (IS) and 0.71 (MC), indicating a higher contribution to $\mathrm{PM}_{10}$ samples of coarse particles for IS and of fine fraction for MC. Together with results for $\mathrm{CN}$ site (0.63) and Bucharest (from 0.7 for industrial sites to 0.8 for a traffic site in the very centre of the city), our observations are consistent with the $\mathrm{PM}_{2.5} / \mathrm{PM}_{10}$ mass ratios from 0.5 to 0.9 at most sites across the Europe.

As shown in Figure 4c, the annual average $\mathrm{SO}_{2}$ concentration in IS was $6.92 \mu \mathrm{g} \mathrm{m}^{-3}$ in 2006 and has gradually decreased to $3.45 \mu \mathrm{g} \mathrm{m}^{-3}$ in 2013, and in CN decreased from 6.83 to $5.69 \mu \mathrm{g} \mathrm{m}^{-3}$. Lower values were observed for regional MC and remote PS sites. The decrease in ambient concentrations of $\mathrm{SO}_{2}$ and $\mathrm{CO}$ in IS was related to lower local emissions of $\mathrm{SO}_{2}$ and $\mathrm{CO}$ based on the positive correlation ambient-emitted $\mathrm{SO}_{2}$ and $\mathrm{CO}$, respectively $\left(\mathrm{COR}_{\mathrm{SO}_{2}}=0.94\right.$; $\left.\mathrm{COR}_{\mathrm{CO}}=0.96\right)$. The same conclusion stands for $\mathrm{CO}$ in Cluj-Napoca, but in a lower extent for $\mathrm{SO}_{2}\left(\mathrm{COR}_{\mathrm{SO} 2}=0.41\right)$. For PS site, the ambient $\mathrm{SO}_{2}$ concentrations increased slightly from 4.67 to $6.91 \mathrm{\mu g} \mathrm{m}^{-3}$, especially due to intensive use of coal for residential household activities. Multiannual average temperature at $\mathrm{PS}$ is $4.3^{\circ} \mathrm{C}$.

The annual averages of $\mathrm{NOx}$ and $\mathrm{O}_{3}$ concentrations show a lower variability at each site, their average values 2006-2013 varying between 40 (42) $\mu \mathrm{g} \mathrm{m}^{-3}$ and 55 (34) $\mathrm{\mu g} \mathrm{m}^{-3}$ in mid-sized cities IS and $\mathrm{CN}$, respectively.

All the gaseous pollutant concentrations at studied sites here are at least one order of magnitude lower than the values observed in Bucharest. [16, 39]. 
(a)
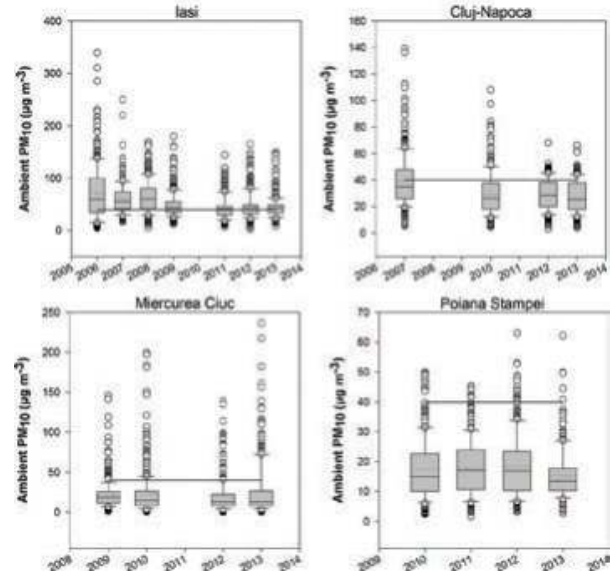

(b)
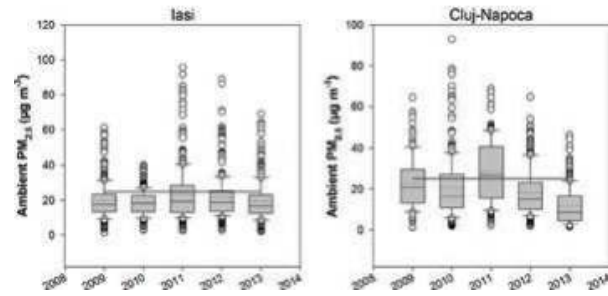

(c)
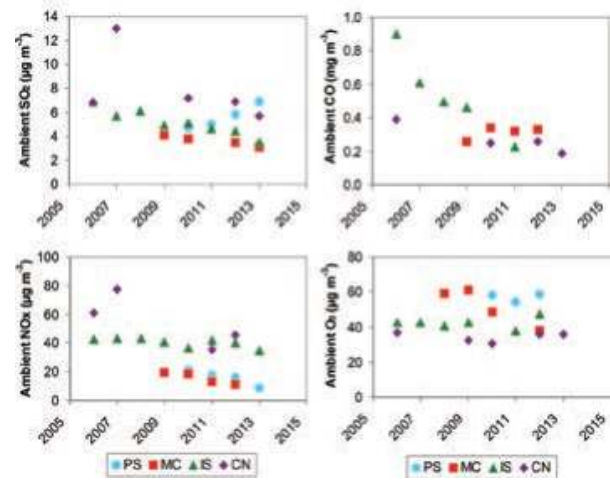

Figure 4. a) Levels of daily $\mathrm{PM}_{10}$ mass concentrations for the specified monitoring periods by each site, including median, the $5^{\text {th }}, 25^{\text {th }}, 75^{\text {th }}$ and the $95^{\text {th }}$ percentiles of their $24 \mathrm{~h}$ concentrations. Dotted line within boxes represents the annual average. The EU annual limit value of $40 \mu \mathrm{g} \mathrm{m}^{-3}$ (long continuous line) is included. Black circles represent first and last $5 \%$ of observed $\mathrm{PM}_{10}$. b) As in Figure $4 \mathrm{a}$, but for $\mathrm{PM}_{2.5}$ concentrations. Long continuous line represents the EU-2015 limit value of $25 \mathrm{\mu g} \mathrm{m}^{-3}$. c) Annual variation of gaseous pollutants by site.. 


\subsubsection{Seasonal variability and site inter-comparison}

The seasonal variability (Table 4) and inter-site comparison (Table 5) were investigated using the coefficient of divergence (COD) and coefficient of correlation (COR). As an example, Figure 5 shows the extreme differences between seasons in Iasi.

\begin{tabular}{llllllll}
\hline & & IS & & & \multicolumn{3}{l}{ CN } \\
\hline Season & Spring & Summer & Autumn & Season & Spring & Summer & Autumn \\
\hline Winter & 0.22 & 0.33 & 0.14 & Winter & 0.30 & 0.30 & 0.17 \\
Spring & & 0.15 & 0.17 & Spring & & 0.19 & 0.34 \\
Summer & & & 0.25 & Summer & & & 0.34 \\
\hline
\end{tabular}

\begin{tabular}{llllllll}
\hline \multicolumn{2}{l}{ MC } & & & \multicolumn{2}{c}{ PS } \\
\hline Season & Spring & Summer & Autumn & Season & Spring & Summer & Autumn \\
\hline Winter & 0.39 & 0.39 & 0.38 & Winter & 0.11 & 0.11 & 0.07 \\
Spring & & 0.26 & 0.29 & Spring & & 0.07 & 0.12 \\
Summer & & & 0.29 & Summer & & 0.12 \\
\hline
\end{tabular}

Table 4. Seasonal variability per site using COD calculated from multi-seasonal average pollutant concentrations.

COD values for the pairs of seasons ranged from 0.07 to 0.12 at PS site, and this indicates almost no seasonality here. Seasonal changes in pollutant concentrations were modest for SpringSummer and Winter-Autumn for IS and CN, and surprisingly, some season-to-season variability appears at MC site.

\begin{tabular}{|c|c|c|c|c|c|c|c|c|c|}
\hline \multirow[b]{2}{*}{ Site } & \multicolumn{4}{|c|}{ Coefficients of divergence (COD) } & \multirow[b]{2}{*}{ Site } & \multicolumn{4}{|c|}{ Inter-sites' correlation coefficients (COR) } \\
\hline & MC & IS & $\mathrm{CN}$ & Bucharest & & MC & IS & $\mathrm{CN}$ & Bucharest \\
\hline PS & 0.51 & 0.61 & 0.56 & 0.46 & PS & 0.99 & 0.6 & 0.48 & 0.66 \\
\hline $\mathrm{MC}$ & & 0.28 & 0.29 & 0.37 & $\mathrm{MC}$ & & 0.71 & 0.56 & 0.75 \\
\hline IS & & & 0.21 & 0.22 & IS & & & 0.83 & 0.95 \\
\hline $\mathrm{CN}$ & & & & 0.20 & $\mathrm{CN}$ & & & & 0.91 \\
\hline
\end{tabular}

Table 5. Comparisons between sites using COD and COR calculated from multi-annual average pollutant concentrations.

Overall, the inter-site calculated COR indicates a positive correlation among all sites suggesting that they all suffer from the same pollution source categories. A very similar situation was found to characterize Greater Bucharest Area (COR varies from 0.55 to 0.88 ) and the Greater Athens Area, where COR varies from 0.55 to 0.84 [44]. However, COD values differentiate the sites, showing: air pollution at the remote PS site is very different from that of all the other 
sites; cities Iasi, Cluj-Napoca and Bucharest are relatively similar, and air pollution at regional rural MC site is relatively different from the others. The highest contributor to COD value of the paired PS-IS sites is $\mathrm{PM}_{10}$, and highest contributors to COD for the pair MC-Bucharest are $\mathrm{NOx}, \mathrm{PM}_{10}$ and $\mathrm{PM}_{2.5}$.
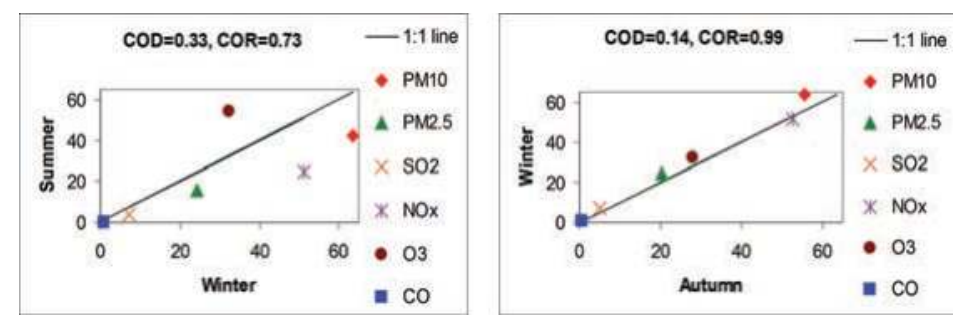

Figure 5. Coefficients of divergence between two seasons for the multi-seasonal average concentrations of pollutants for Iasi site.

\subsubsection{Associations between particulate matter levels and gaseous pollutants-meteorology influence}

Table 6 synthesizes the relationships between daily $\mathrm{PM}_{10}$ and $\mathrm{PM}_{2.5}$ and daily averaged gaseous pollutant concentrations over the entire sampling periods up to 2013 per site. It shows good correlations between both $\mathrm{PM}_{10}\left(\mathrm{PM}_{2.5}\right)-\mathrm{NO}_{\mathrm{x}}$ and $\mathrm{PM}_{10}\left(\mathrm{PM}_{2.5}\right)-\mathrm{CO}$, and a less-defined correlation with $\mathrm{SO}_{2}$. However, the strength of these correlations varies among sites: probably a common road traffic origin in cities IS and $\mathrm{CN}$ but with differences in contribution percentages of NOx versus $\mathrm{CO}$ (IS has a higher percentage of old vehicles than $\mathrm{CN}$ ), a lower capability of the area to disperse the pollutants at MC site, low traffic and higher coal and wood combustion at the remote site PS.

Similar correlation coefficients (0.4-0.8 for $\mathrm{PM}_{10}-\mathrm{NO}_{x}$ relationship, about 0.4-0.7 for $\left.\mathrm{PM}_{10}-\mathrm{CO}\right)$ were reported at different sites in UK and Greece [45]. Bucharest data indicate correlation coefficients of $0.4-0.7$ for $\mathrm{PM}_{10}-\mathrm{NO}_{x}$ relationship, 0.2-0.5 for $\mathrm{PM}_{10}-\mathrm{CO}$ relationship and 0.1-0.4 for $\mathrm{PM}_{10}-\mathrm{SO}_{2}$ relationship. The daily mean $\mathrm{O}_{3}$ concentrations negatively correlated with both $\mathrm{PM}_{10}$ and $\mathrm{PM}_{2.5}$ could be explained by the reaction of $\mathrm{O}_{3}$ with $\mathrm{NO}$, which is a major sink for $\mathrm{O}_{3}$. At the site $\mathrm{MC}$, a positive correlation $\mathrm{PM}_{10}-\mathrm{O}_{3}$ appears. As in some situations in the UK atmosphere [46], short periods with positive correlation $\mathrm{PM}-\mathrm{O}_{3}$ during photochemical episodes were reported in Bucharest Greater Area during 2005-2007 [39]. Our positive

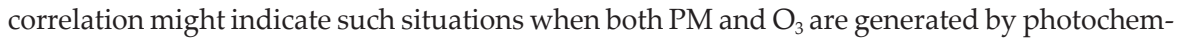
ical activity for MC in warm season, but the calculated coefficient is very low, and probably these episodes are swamped by the 4-year analysis.

The associations between $\mathrm{PM}_{10}$ and primary gaseous pollutant levels were investigated further by multiple linear regressions performed using daily mean $\mathrm{PM}_{10}$ values and daily averaged gaseous pollutants $\mathrm{NO}_{x}, \mathrm{SO}_{2}$ and $\mathrm{CO}$ for the same periods. For each pollutant, the multiple regressions were performed only for $\mathrm{NOx}, \mathrm{SO}_{2}$ and $\mathrm{CO}$ for which single correlation coefficients with $\mathrm{PM}_{10}$ were higher than 0.30 (Table 6). The multivariate linear regression model is widely 
recognized as a useful tool to show associations between primary pollutants [36, 46], to calculate combustion/non-combustion fraction of PM [45] or to predict daily concentrations of $\mathrm{PM}$ [47]. For present sites, the model was applied assuming $\mathrm{NOx}, \mathrm{SO}_{2}$ and $\mathrm{CO}$ as tracers for anthropogenic activities. In this model, slopes will represent the association of anthropogenic activities with $\mathrm{PM}_{10}$ (contribution of anthropogenic activities to $\mathrm{PM}_{10}$ ), and intercepts are assumed to represent the non-anthropogenic contribution (the natural contribution) to $\mathrm{PM}_{10}$. The natural contributions to $\mathrm{PM}_{10}$ thus re-constructed are shown in Figure 6 for each site.

\begin{tabular}{|c|c|c|c|c|c|c|c|c|c|c|c|c|c|}
\hline \multicolumn{7}{|c|}{ IS } & \multicolumn{7}{|c|}{$\mathrm{CN}$} \\
\hline & $\mathrm{PM}_{10}$ & $\mathrm{PM}_{2.5}$ & NOx & $\mathrm{O}_{3}$ & $\mathrm{SO}_{2}$ & $\mathrm{CO}$ & & $\mathbf{P M}_{10}$ & $\mathrm{PM}_{2.5}$ & NOx & $\mathrm{O}_{3}$ & $\mathrm{SO}_{2}$ & $\mathrm{CO}$ \\
\hline $\mathrm{PM}_{10}$ & 1.00 & 0.70 & 0.56 & -0.13 & 0.34 & 0.64 & $\mathrm{PM}_{10}$ & 1.00 & 0.73 & 0.64 & -0.21 & 0.32 & 0.53 \\
\hline $\mathrm{PM}_{2.5}$ & & 1.00 & 0.56 & -0.19 & 0.26 & 0.59 & $\mathrm{PM}_{2.5}$ & & 1.00 & 0.46 & -0.27 & 0.32 & 0.59 \\
\hline NOx & & & 1.00 & -0.49 & 0.36 & 0.79 & NOx & & & 1.00 & -0.63 & 0.25 & 0.63 \\
\hline $\mathrm{O}_{3}$ & & & & 1.00 & -0.12 & -0.44 & $\mathrm{O}_{3}$ & & & & 1.00 & -0.15 & -0.46 \\
\hline $\mathrm{SO}_{2}$ & & & & & 1.00 & 0.46 & $\mathrm{SO}_{2}$ & & & & & 1.00 & 0.31 \\
\hline $\mathrm{CO}$ & & & & & & 1.00 & $\mathrm{CO}$ & & & & & & 1.00 \\
\hline \multicolumn{7}{|c|}{ MC } & \multicolumn{7}{|c|}{ PS } \\
\hline & $\mathrm{PM}_{10}$ & $\mathrm{PM}_{2.5}$ & NOx & $\mathrm{O}_{3}$ & $\mathrm{SO}_{2}$ & $\mathrm{CO}$ & & $\mathbf{P M}_{10}$ & $\mathrm{PM}_{2.5}$ & NOx & $\mathrm{O}_{3}$ & $\mathrm{SO}_{2}$ & $\mathrm{CO}$ \\
\hline $\mathrm{PM}_{10}$ & 1.00 & 0.95 & 0.81 & 0.05 & 0.24 & 0.91 & $\mathrm{PM}_{10}$ & 1.00 & - & 0.37 & -0.13 & 0.13 & 0.64 \\
\hline $\mathrm{PM}_{2.5}$ & & 1.00 & - & - & 0.57 & - & $\mathrm{PM}_{2.5}$ & & 1.00 & - & - & - & - \\
\hline $\mathrm{NOx}$ & & & 1.00 & -0.18 & 0.09 & 0.83 & NOx & & & 1.00 & -0.45 & -0.19 & 0.54 \\
\hline $\mathrm{O}_{3}$ & & & & 1.00 & 0.33 & -0.12 & $\mathrm{O}_{3}$ & & & & 1.00 & -0.07 & -0.49 \\
\hline $\mathrm{SO}_{2}$ & & & & & 1.00 & 0.07 & $\mathrm{SO}_{2}$ & & & & & 1.00 & 0.05 \\
\hline $\mathrm{CO}$ & & & & & & 1.00 & $\mathrm{CO}$ & & & & & & 1.00 \\
\hline
\end{tabular}

Table 6. Correlation coefficients between daily $\mathrm{PM}_{10}$ and $\mathrm{PM}_{2.5}$ and daily averaged gaseous pollutant concentrations.

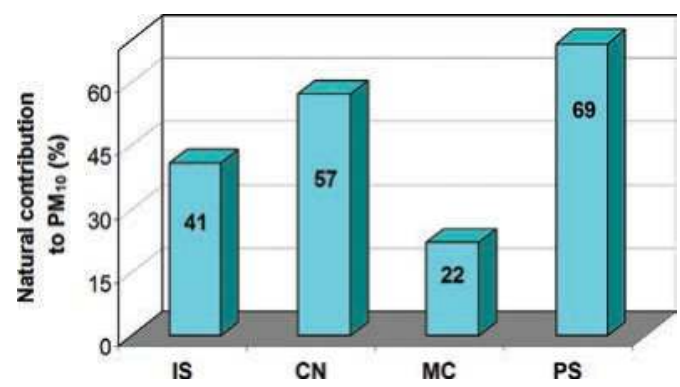

Figure 6. Chart showing re-constructed natural contributions to $\mathrm{PM}_{10}$ by site. 


\begin{tabular}{|c|c|c|c|c|c|}
\hline Site & Temperature & Atmospheric pressure & Relative humidity & Wind speed & Wind direction \\
\hline \multicolumn{6}{|c|}{$\mathrm{PM}_{10}$} \\
\hline IS $(n=2068)$ & -0.18 & 0.15 & -0.13 & -0.10 & -0.12 \\
\hline $\mathrm{CN}(\mathrm{n}=1327)$ & -0.22 & 0.16 & -0.12 & -0.19 & -0.34 \\
\hline $\mathrm{MC}(\mathrm{n}=1339)$ & -0.55 & 0.08 & 0.22 & -0.37 & -0.09 \\
\hline PS (n=1199) & -0.16 & 0.20 & -0.20 & -0.40 & -0.02 \\
\hline \multicolumn{6}{|c|}{$\mathrm{PM}_{2.5}$} \\
\hline IS $(n=1733)$ & -0.32 & 0.27 & 0.05 & -0.14 & -0.13 \\
\hline $\mathrm{CN}(\mathrm{n}=1327)$ & -0.48 & 0.17 & 0.16 & -0.26 & -0.30 \\
\hline $\mathrm{MC}(\mathrm{n}=326)$ & -0.51 & 0.05 & 0.29 & -0.42 & -0.14 \\
\hline
\end{tabular}

$\mathrm{n}=$ number of samples used in analysis.

Table 7. Correlation coefficients between daily $\mathrm{PM}_{10}$ and $\mathrm{PM}_{2.5}$ and daily averaged local meteorological variables.

Correlation analysis of PM and daily averaged local meteorological variables (Table 7) revealed a similar behavior for $\mathrm{PM}_{10}$ and $\mathrm{PM}_{2.5}$ with all parameters with the exception of $\mathrm{PM}$ relationship with the relative humidity.

The negative correlations of $\mathrm{PM}_{10}$ and $\mathrm{PM}_{2.5}$ with temperature, relative humidity and wind speed indicate dilution of ambient concentrations of PM due to an increased atmospheric boundary layer, scavenging by fog or cloud droplets and deposition onto ground surfaces (precipitation data were not available) and dispersion of particles, especially of fine fraction, by winds. The negative correlation with temperature could be due also to increased emissions (Figure 3) or a reduced dispersion (highest coefficients were obtained at MC site) and stable atmospheric conditions (atmospheric pressure) during cold seasons. In cold seasons, low speed wind conditions and lower temperature could result in a lower boundary layer that traps pollution to the ground. In warm seasons, more intense winds, higher temperature (that could reflect positive correlations with solar radiation) and higher boundary layer could result in pollution transport. The multi-annual averages of relative humidity for the corresponding monitored periods have high values for all sites: 72\% (IS), 77\% (CN), 81\% (MC) and 82\% (PS). Relative humidity values in the range $70-90 \%$ for MC and PS sites appeared frequently, and they were found to be associated with low winds; temperature inversion episodes in MC and PS areas are frequently mentioned in climatology, as well. These combined factors might explain the positive correlation $\mathrm{PM}_{10}$-relative humidity.

The $\mathrm{PM}_{10}$ and $\mathrm{PM}_{2.5}$ dependence of wind direction (Figure 7 indicates this dependence for $\mathrm{PM}_{10}$, but $\mathrm{PM}_{2.5}$ presents the same distribution) gives certain insights into the distribution of emission sources around the selected monitoring sites. Particulate matter concentrations are associated with southwesterly winds for MC, while in larger cities IS and CN the $\mathrm{PM}_{10}$ and $\mathrm{PM}_{2.5}$ are distributed relatively equal in all sectors with the exception of NW-NE sector. Highest $\mathrm{PM}_{10}$ concentrations (range: $60-80 \mathrm{\mu g} \mathrm{m}^{-3}$ ) appear to come from S-SE directions in ClujNapoca, and highest $\mathrm{PM}_{10}$ (from 100 to $180 \mathrm{\mu g} \mathrm{m}^{-3}$ ) come from all directions between $\mathrm{NE}$ and NNW in Iasi. At the remote site PS, the highest $\mathrm{PM}_{10}$ levels (of about $60 \mathrm{\mu g} \mathrm{m}^{-3}$ ) appeared on 
the direction NE-SW, whereas intermediate and low values are associated to all directions from NE to NW.

If one compares meteorological factors that influence the concentration of particulates for the above sites, it results that the most important are temperature, wind speed, humidity and, on the last position, the atmospheric pressure. For Bucharest, the order is changed: wind speed, temperature, atmospheric pressure and humidity. A literature survey revealed that wind speed, relative humidity and temperature seem to compete for the first position, but also their squared terms and interactions between them play some role. In any case, the order of importance of meteorological variable influences on ambient PM levels is regional in nature, and no general conclusion might be drawn.
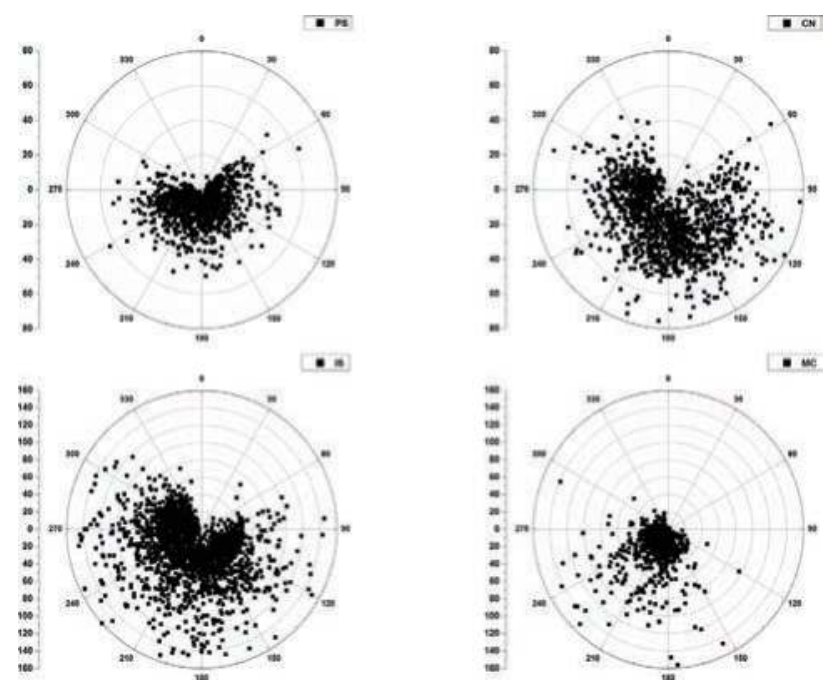

Figure 7. Mass concentrations of $\mathrm{PM}_{10}$ with respect to wind direction by each site. $\mathrm{PM}_{2.5}$ shows the same pattern.

\subsection{Pollutant trends: annual and seasonal}

Pollutant annual and seasonal average concentrations at all sites were further investigated in order to determine if temporal trends could be revealed. Calculated annual trends (Table 8) indicate the most pronounced decreases for $\mathrm{PM}_{10}$ at IS site $\left(-3.6 \% \mathrm{yr}^{-1}\right)$, for $\mathrm{NOx}$ at MC $(-3.1 \%$ $\mathrm{yr}^{-1}$ ) and stability in $\mathrm{CN}$ area. A slight increasing trend for $\mathrm{SO}_{2}$ was detected at PS remote site. The annual pollutant trends follow only partial trends of emissions, depending on the site, as it results from a comparison of data in Table 8 with graphs in Figure 3. Seasonal trends at PS, $\mathrm{MC}$ and $\mathrm{CN}$ sites showed the same behaviors as annual pollutant trends for all seasons, whereas in Iasi some seasonality could be observed. Here, $\mathrm{PM}_{10}, \mathrm{CO}$ and $\mathrm{SO}_{2}$ decrease mainly during winter, whereas the maximum decrease of NOx appeared in autumn (associated with 
maximum increase of $\mathrm{O}_{3}$ ). All estimated trends are lower than those calculated for Bucharest area [36, 39], where for example, $\mathrm{SO}_{2}$ annual trends varied between $-1.28 \% \mathrm{yr}^{-1}$ and $-3.73 \% \mathrm{yr}^{-1}$. More pronounced reductions in $\mathrm{SO}_{2}$ (from -6.6 to $-14.9 \% \mathrm{yr}^{-1}$ ) were recently reported for $\mathrm{UK}$ [48], whereas for various stations across Europe, percentage reductions of $\mathrm{PM}_{2.5}$ varied from 7 to $49 \%$ during the $2002-2010$ period [49].

\begin{tabular}{|c|c|c|c|c|c|c|c|c|c|c|c|c|}
\hline \multirow[t]{2}{*}{ Site/Pollutant } & \multicolumn{3}{|c|}{ PS } & \multicolumn{3}{|c|}{ MC } & \multicolumn{3}{|c|}{ IS } & \multicolumn{3}{|c|}{$\mathrm{CN}$} \\
\hline & $\mathrm{S}$ & Q & Trend & $\mathrm{S}$ & $\mathrm{Q}$ & Trend & $\mathrm{S}$ & Q & Trend & $S$ & Q & Trend \\
\hline $\mathrm{PM}_{10}$ & 0 & -0.1 & Stable & 4 & 1.3 & Stable & -15 & -3.6 & Decreasing & -4 & -2.0 & Stable \\
\hline $\mathrm{PM}_{2.5}$ & nd & nd & nd & nd & nd & nd & 0 & 0.1 & Stable & -6 & -2.3 & Stable \\
\hline $\mathrm{NO}_{x}$ & -6 & -3.8 & Decreasing & -6 & -3.1 & Decreasing & -18 & -0.8 & Decreasing & -2 & -3.8 & Stable \\
\hline $\mathrm{O}_{3}$ & nd & nd & nd & -4 & -5.3 & Stable & -2 & -0.1 & Stable & 0 & $0.01^{*}$ & Stable \\
\hline $\mathrm{SO}_{2}$ & 6 & 0.8 & Increasing & -6 & -0.3 & Decreasing & -24 & -0.4 & Decreasing & -4 & -0.3 & Stable \\
\hline $\mathrm{CO}$ & nd & nd & nd & 2 & $0.02^{*}$ & No trend & -10 & -0.1 & Decreasing & -4 & $-0.03^{*}$ & Stable \\
\hline
\end{tabular}

All trends are statistically significant at level of significance at least 0.1 (corresponding to $10 \%$ chance there is no trend) unless otherwise indicated.

"Trend non-significant; nd-not determined; S-Mann-Kendall statistics; Q-Sen's slope estimate.

Table 8. Pollutant annual trends, calculated as percent change per unit time.

In southeastern United States, decreasing trends from -5.1 to $-9.7 \% \mathrm{yr}^{-1}$ for $\mathrm{SO}_{2}$ and decreases of annual mean $\mathrm{CO}$ and NOx concentrations at rates ranging from -1.2 to $-7.2 \% \mathrm{yr}^{-1}$ (-6.0 to $-9.0 \% \mathrm{yr}^{-1}$ ) were reported [50], which are also higher than the corresponding decreasing rates determined for all selected locations in Romania. However, calculated temporal trends of main pollutants during 1997-2012 in Makkah, Saudi Arabia, indicate both increases (3.4\% $\mathrm{yr}^{-1}$ for $\mathrm{PM}_{10}, 6.1 \% \mathrm{yr}^{-1}$ for $\mathrm{SO}_{2}, 4.7 \% \mathrm{yr}^{-1}$ for $\mathrm{O}_{3}$ ) and decreases (-2.6\% $\mathrm{yr}^{-1}$ for $\mathrm{CO},-3.5 \% \mathrm{yr}^{-1}$ for $\mathrm{NO}$ ) [51]. Among potential factors responsible for the observed trends all over the world are emissions for traffic, changing weather patterns, construction activities, windblown re-suspensions, emissions of $\mathrm{O}_{3}$ anthropogenic precursors, whose predominance is of regional nature, but large-scale meteorological phenomena (North Atlantic Oscillation for example), implementation of pollution abatement strategies or the economic crisis influences are also important [52].

\section{Conclusion}

This study contributes to the knowledge on air pollution in East Europe, presenting an updated assessment of the ground-level concentrations of major air pollutants in different environments, from highest to background values, and using data covering the longest available time period. Ambient air pollution levels, their variability and trends are discussed in the context of air quality status and trends in Bucharest, Europe and worldwide. Specific-air pollutant trends are analyzed in order to show if they follow the trend of pollutant emissions. 


\section{Acknowledgements}

The air pollution data were extracted from European AQ database Airbase v.8 (accessed in July 2015), and meteorological data from http://rp5.ru for WMO_ID=15069, 15090, 15120, 15170 stations. The author acknowledges the team of Google Earth.

\section{Author details}

Gabriela Iorga*

Address all correspondence to: gabriela.iorga@g.unibuc.ro

University of Bucharest, Department of Physical Chemistry (Physics Group), Bucharest, Romania

\section{References}

[1] World Health Organization. http://www.who.int/topics/air_pollution/en/ [Accessed: 2016-06-23]

[2] Jacobson MZ. Atmospheric Pollution: History, Science and Regulation. Cambridge University Press, Cambridge, UK; 2002. 412 p.

[3] Abdul-Wahab SA, En SCF, Elkamel A, Ahmadi L, Yetilmezsoy K. A review of standards and guidelines set by international bodies for the parameters of indoor air quality. Atmos. Poll. Res. 2015; 6: 751-767.

[4] Hang J, Sandberg M, Claesson L. Pollutant dispersion in idealized city models with different urban morphologies. Atmos. Environ. 2009; 43: 6011-6025.

[5] Gromke C, Jamarkattel N, Ruck B. Influence of roadside hedgerows on air quality in urban street canyons. Atmos. Environ. 2016; 139: 75-86.

[6] Pope CA, Dockery DW. Health effects of fine particulate air pollution: lines that connect. J Air Waste Manag. Assoc. 2006; 56:709-742.

[7] Ramos-Bonilla JP, Breysse PN, Dominici F, Geyh A, Tankersley CG. Ambient air pollution alters heart rate regulation in aged mice. Inhal Toxicol. 2010; 22: 330-339.

[8] Wilson WE, Suh HH. Fine particles and coarse particles: ion concentration relationships relevant to epidemiological studies. J. Air and Waste Manag. Assoc. 1997; 47: 1238-1249.

[9] Grice S, Stedman J, Kent A, Hobson M, Norris J, Abbott J, Cooke S. Recent trends and projections of primary $\mathrm{NO}_{2}$ emissions in Europe. Atmos. Environ. 2009; 43: 2154-2 167. 
[10] EEA. Air Pollution fact sheet 2014-Romania. Available from: www.eea.europa.eu [Accessed: 2014-12-23].

[11] Laj P, Klausen J, Bilde M, Plaß-Duelmer C, Papalardo G, et al. Measuring atmospheric composition change. Atmos. Environ. 2009; 43: 5351-5414.

[12] Kuklinska K, Wolska L, Namiesnik J. Air quality policy in the U.S. and the EU-a review. Atmos. Poll. Res. 2015; 6: 129-137.

[13] Gulia S, Nagendra SMS, Khare M, Khanna I. Urban air quality management-a review. Atmos. Poll. Res. 2015; 6: 286-304.

[14] World Health Organization. WHO air quality guidelines for particulate matter, ozone, nitrogen dioxide and sulfur dioxide. Global update 2005. 2006. Available from http:// www.who.int/mediacentre/factsheets/fs313/en/ [Accessed: 2016-06-23]

[15] US EPA. Environmental Protection Agency National Ambient Air Quality Standards. Updated in 2015. Available from https://www.epa.gov/criteria-air-pollutants/naaqstable [Accessed: 2016-06-23]

[16] Iorga G, Balaceanu-Raicu C, Stefan S. Supporting material of annual air pollution level of major primary pollutants in Greater Area of Bucharest. Atmos. Poll. Res. 2015; 6: S1S18.

[17] EURAD, AQI. Available from: http://www.eurad.uni-koeln.de/index_e.html

[18] (AQHI Canada) Environment and climate change Canada. Air Quality Health Index. http://www.ec.gc.ca/cas-aqhi/default.asp?lang=En\&n=065BE995-1

[19] China REF AQI China. http://aqicn.org/city/nanjing/ [Accessed 2016-07-07]

[20] INDIA, Central Pollution Control Board. http://www.cpcb.nic.in/FINAL-REPORT_AQI_.pdf [Accessed 2016-07-07]

[21] US EPA. Technical Assistance Document for the Reporting of Daily Air Quality - the Air Quality Index (AQI). EPA-454/B-09-001. 2009; 31p.

[22] EUCITEAIR http://www.airqualitynow.eu/download/CITEAIR-Comparing_Urban_Air_Quality_across_Borders.pdf [Accessed 2016-07-07]

[23] EPA, AQI calculator_Concentration to AQI https://www.airnow.gov/index.cfm? action=resources.conc_aqi_calc [Accessed 2016-07-07]

[24] Plaia A, di Salvo F, Ruggieri M, Agro G. A multisite-multipollutant air quality index. Atmos. Environ. 2013; 70: 387-391.

[25] Plaia A, Ruggieri M. Air quality indices: a review. Rev Environ Sci Biotechnol. 2011; 10: 165-179.

[26] Cheng WL, Chen Y, Zhang J, Lyons TJ, Pai JL, Chang SH. Comparison of the Revised Air Quality Index with the PSI and AQI indices. Sci. Total Environ. 2007; 382: 191-198. 
[27] Elshout S van den, Léger K, Nussio F. Comparing urban air quality in Europe in real time: a review of existing air quality indices and the proposal of a common alternative. Environ. Int. 2008; 34: 720-726.

[28] Glotfelty T, Zhang Y, Karamchandani P, Streets DG. Changes in future air quality, deposition, and aerosol-cloud interactions under future climate and emission scenarios. Atmos. Environ. 2016; 139: 176-191.

[29] OECD. The Economic Consequences of Outdoor Air Pollution: OECD Publishing, Paris; 2016. http://dx.doi.org/10.1787/9789264257474-en

[30] Leitte AM, Petrescu C, Franck U, Richter M, Suciu O, Ionovici R, Herbarth O, Schlink U. Respiratory health, effects of ambient air pollution and its modification by air humidity in Drobeta-Turnu Severin, Romania. Sci. of Total Environ. 2009; 407: 40044011.

[31] Haiduc I, Beldean-Galea, MS. Variation of greenhouse gases in urban areas-case study: $\mathrm{CO}_{2}, \mathrm{CO}$ and $\mathrm{CH}_{4}$ in three Romanian cities, in Air Quality-Models and Applications, edited by Popovic D, INTech, UK. 2011; pp. 289-318.

[32] Popescu F, Ionel I, Lontis N, Calin L, Dungan IL. Air quality monitoring in an urban agglomeration. Rom. J. Phys. 2011; 56: 495-506.

[33] Pehoiu G. and Murărescu O. (2012). Pollution and Air Quality in Târgoviste Municipality and Its Surroundings (Romania), Air Pollution-Monitoring, Modelling, Health and Control, Dr. Mukesh Khare (Ed.), ISBN: 978-953-51-0381-3, InTech.

[34] Grigoras G, Mocioaca G. Air quality assessment in Craiova urban area. Rom. Rep. Phys. 2012; 64: 768-787.

[35] Soporan VF, Nascutiu L, Soporan B, Pavai C. Case studies of methane dispersion patterns and odor strength in vicinity of municipal solid waste landfill of Cluj-Napoca, Romania, using numerical modeling. Atmos. Poll. Res. 2015; 6: 312-321.

[36] Iorga G, Balaceanu-Raicu C, Stefan S. Annual air pollution level of major primary pollutants in Greater Area of Bucharest. Atmos. Poll. Res. 2015; 6: 824-834.

[37] EEA, 2015. European Environment Agency. European air quality database, www.Eea.Europa.Eu/data-and-maps/data/airbase-the-european-air-quality-database1 [Accessed 2015-07-24]

[38] Monks PS. A review of the observations and origins of the spring ozone maximum. Atmos. Environ. 2000; 34: 3545-3561.

[39] Stefan S, Zagar L, Necula C, Barladeanu R, Rada C. Assessment of surface-ozone in Bucharest, Romania focused on trends for three years. Environ. Eng. Manag. J. 2013; 13: $241-250$.

[40] Salmi T, Määttä A, Anttila P, Ruoho-Airola T, Amnell T. 2002. Detecting trends of annual values of atmospheric pollutants by the Mann-Kendall test and Sen's slope estimates- 
the Excel template application MAKESENS, Helsinki, Finnish Meteorological Institute. Report Code fmi-aq-31.

[41] EMEP/CEIP 2015 Present state of emissions as used in EMEP models; http:// www.ceip.at/webdab_emepdatabase/emissions_emepmodels/. [Accessed 2016-05-03]

[42] EEA. Air Quality in Europe-2015 Report. European Environment Agency. 5/2015 www.eea.europa.eu [Accessed 2016-05-03].

[43] Ambient Air Quality Directive 2008/50/EC of the European Parliament and of the Council of 21 May 2008 on ambient air quality and cleaner air for Europe, Official Journal of the European Union L 152/11.6.2008, p. 1-44.

[44] Grivas G, Chaloulakou A, Kassomenos P. An overview of the $\mathrm{PM}_{10}$ pollution problem, in the Metropolitan Area of Athens, Greece: assessment of controlling factors and potential impact of long-range transport. Sci. Total Environ. 2008; 389:165-177.

[45] Vardoulakis S, Kassomenos P. Sources and factors affecting PM10 levels in two European cities: implications for local air quality management. Atmos. Environ. 2008; 42: 3949-3963.

[46] Harrison RM, Laxen D, Moorcroft S, Laxen K. Processes affecting concentrations of fine particulate matter (PM2.5) in the UK atmosphere. Atmos. Environ. 2012; 46: 115-124.

[47] Dimitriou K, Kassomenos P. A study on the reconstitution of daily $\mathrm{PM}_{10}$ and $\mathrm{PM}_{2.5}$ levels in Paris with a multivariate linear regression model. Atmos. Environ. 2014; 98: 648-654.

[48] Jones AM, Harrison RM. Temporal trends in sulphate concentrations at European sites and relationships to sulphur dioxide. Atmos. Environ. 2011; 45: 873-882.

[49] Cusack M, Alastuey A, Perez N, Pey J, Querol X. Trends of particulate matter (PM2.5) and chemical composition at a regional background site in the Western Mediterranean over the last nine years (2002-2010). Atmos. Chem. Phys. 2012; 12: 8341-8357.

[50] Blanchard CL, Hidy GM, Tanenbaum S, Edgerton ES, Hartsell BE. The southeastern aerosol research and characterization (SEARCH) study: temporal trends in gas and PM concentrations and composition, 1999-2010. J. Air \& Waste Manag. Assoc. 2013; 63: 247259.

[51] Munir S, Habeebullah TM, Seroji AR, Gabr SS, Mohammed AMF, Morsy EA. Quantifying temporal trends of atmospheric pollutants in Makkah (1997-2012). Atmos. Environ. 2013; 77: 647-655.

[52] Cape JN. Surface ozone concentrations and ecosystem health: past trends and a guide to future projections. Sci. Total Environ. 2008; 400: 257-269. 